\title{
Strategic and Tactical Prediction of Forage Production in Northern Mixed-Grass Prairie
}

\author{
Allan A. Andales, ${ }^{1}$ Justin D. Derner, ${ }^{2}$ \\ Lajpat R. Ahuja, ${ }^{3}$ and Richard H. Hart ${ }^{4}$ \\ Authors are ${ }^{1}$ Soil Scientist and ${ }^{3}$ Soil Scientist/Research Leader, USDA-Agricultural Research Service- \\ Agricultural Systems Research Unit, 2150 Centre Ave, Bldg D, Suite 200, Fort Collins, CO 80526; ${ }^{2}$ Rangeland \\ Scientist and ${ }^{4}$ Rangeland Scientist (retired), USDA-Agricultural Research Service-High Plains Grasslands \\ Research Station, 8408 Hildreth Rd, Cheyenne, WY 82009.
}

\begin{abstract}
Predictions of forage production derived from site-specific environmental information (e.g., soil type, weather, plant community composition, and so on) could help land managers decide on appropriate stocking rates of livestock. This study assessed the applicability of the Great Plains Framework for Agricultural Resource Management (GPFARM) forage growth model for both strategic (long-term) and tactical (within-season) prediction of forage production in northern mixed-grass prairie. An improved version of the model was calibrated for conditions at the USDA-ARS High Plains Grasslands Research Station in Cheyenne, Wyoming. Long-term (1983-2001) simulations of peak standing crop (PSC) were compared to observations. Also, within-season (1983) forecasts of total aboveground biomass made for 1 March onward, 1 April onward, 1 May onward, and 1 June onward were compared to observations. The normal, driest, and wettest weather years on record (1915-1981) were used to simulate expected values, lower bounds, and upper bounds of biomass production, respectively. The forage model explained $66 \%$ of the variability in PSC from 1983 to 2001. The cumulative distribution function (CDF) derived from long-term simulated PSC overestimates cumulative probabilities for PSC $>1500 \mathrm{~kg} \cdot \mathrm{ha}^{-1}$. The generated CDF could be used strategically to estimate long-term forage production at various levels of probability, with errors in cumulative probability ranging from 0.0 to 0.16 . Within-season forecasts explained $77 \%-94 \%$ of biomass variability in 1983 . It was shown that monthly updating of the forage forecast, with input of actual weather to date, improves accuracy. Further development and testing of the forage simulation model will focus on the interactions between forage growth, environmental perturbations (especially drought), and grazing.
\end{abstract}

\section{Resumen}

Las predicciones de producción de forraje derivadas de información ambiental específica del sitio (por ejemplo, tipo de suelo, clima, composición de la comunidad vegetal, etc.) puede ayudar a los manejadores de pastizales a decidir sobe las cargas animal adecuadas. Este estudio evaluó la aplicabilidad del modelo de crecimiento de forraje GPFARM para predicciones estratégicas (largo pazo) y tácticas (corto plazo) de producción de forraje en las praderas mezcladas del Norte. Una versión mejorada del modelo fue calibrada para las condiciones de la Estación Experimental High Plains Grassland del USDA-ARS en Cheyenne, Wyoming. Simulaciones de largo plazo (1983-2001) de la máxima producción biomasa se compararon con observaciones. También, se hicieron predicciones dentro de la estación (1983) para la biomasa total aérea del 1 de Marzo, 1 de Abril, 1 de Mayo y 1 de Junio y fueron comparadas con las obsevaciones. Los registros de un año normal, el más seco y el más humedo (1915 a 1981) se usaron para simular los valores esperados, los límites más bajo y más alto de producción de biomasa. El modelo de forraje explicó el 66\% de la variabilidad en el PSC de 1983 a 2001. La función de distribución acumulativa (CDF) derivada del PSC simulado a largo plazo sobreestima las probabilidades acumulativas de PSC por más de $1500 \mathrm{~kg} \cdot \mathrm{ha}{ }^{-1}$. La CDF generada pudierá ser usada estratégicamente para estima la producción de forraje a largo plazo a varios niveles de probabilidad, con errores en la probabilidad acumulativa variando de 0 a 0.16 . Los pronósticos dentro de la estación explicaron de $77 \%$ a $94 \%$ de la variabilidad de la biomasa de 1983. Se demostró que la actualización mensual del pronóstico del 1 de Marzo, con la inclusión de los datos actuales de clima mejora la certeza de la predicción. El desarrollo y evaluación futura del modelo de simulación de forraje se enfocará en las interacciones entre el crecimiento de forraje, perturbaciones ambientales (especialmente sequía) y el apacentamiento.

Key Words: decision support tool, Great Plains Framework for Agricultural Resource Management (GPFARM), modeling, northern Great Plains, peak standing crop, precipitation, simulation model

\section{INTRODUCTION}

Correspondence: Allan A. Andales, USDA-Agricultural Research Service, Agricultural Systems Research Unit, 2150 Centre Ave, BIdg. D, Suite 200, Fort Collins, CO 80526. Email: Allan.Andales@ars.usda.gov

Manuscript received 4 January 2006; manuscript accepted 26 June 2006.
Productivity of semiarid rangeland ecosystems in the North American Great Plains is affected proportionally more by interannual variability in precipitation compared to other ecosystems (Knapp and Smith 2001). As a result, it is often problematic for land managers to properly adjust stocking rates 
between and within years to achieve sustainable use of these lands for livestock production. Because determinations of stocking rate depend on accurate estimates of forage production and determinations of forage production are often time consuming and subject to criticism as a point in time measurement, decision support tools are needed by land managers to assist in strategic (defined as between years) and tactical (defined as within-year) planning efforts. Computer simulation models of forage production have utility in both strategic (e.g., Parsch et al. 1997) and tactical (e.g., Wight et al. 1984) planning applications. For example, predictions of forage production from site-specific environmental information (e.g., soil type, weather, plant community composition, and so on) would provide land managers with information to decide on an initial stocking rate at the beginning of each grazing season and, potentially, information for adjustments of stocking rate during the grazing season. The USDA-Agricultural Research Service (ARS) Great Plains Framework for Agricultural Resource Management (GPFARM) forage growth model (Andales et al. 2005) is envisioned to address both strategic and tactical applications.

Initial testing of the GPFARM forage growth model for strategic planning regarding forage production in a shortgrass prairie determined that the model had functional utility in simulating forage production, but improvement was needed regarding plant responses to environmental stresses (Andales et al. 2005). However, this study evaluated only 3 years of forage production data at this site. Therefore, there was a need to further test the functional ability of the GPFARM forage growth module with more extensive forage production data sets to increase the strategic planning utility. In addition, there was a need to conduct initial tests of the tactical planning ability of the GPFARM forage growth module.

Fortunately, regression relationships have been developed for predicting forage production from precipitation in many rangeland ecosystems (e.g., Launchbaugh 1967; Khumalo and Holechek 2005) including extensive efforts in northern mixedgrass prairie (e.g., Biondini and Manske 1996; Biondini et al. 1998; Heitschmidt et al. 1999). Spring precipitation amounts are a good predictor of forage production in northern mixedgrass prairie because most of the forage production is completed early in the summer because of dominance of C3 perennial grasses (e.g., Biondini and Manske 1996), but they lack robustness as decision support tools for land managers. A better tactical planning tool will likely need to utilize variables such as soil water that can be measured or simulated for real-time decisions. It remains to be determined whether the GPFARM forage growth module can function as a tactical decision support tool, but the model does have components for soil water, root growth and soil water use (Andales et al. 2003).

Our goal in this study was to assess the applicability of the GPFARM forage growth model for both strategic and tactical prediction of forage production in northern mixed-grass prairie. This study takes advantage of a long-term experiment in southeastern Wyoming in which forage production data have been obtained since 1982 (Hart et al. 1988; Manley et al. 1997). The specific objectives were 1) to assess the accuracy of GPFARM predictions of forage production compared to annual observations of peak standing crop (strategic prediction utility) and 2) to assess GPFARM predictions of within-growing season forage production based on initial soil water content in spring (tactical prediction utility).

\section{MATERIALS AND METHODS}

\section{Improved GPFARM Forage Module}

Andales et al. (2005) previously described the major plant processes simulated. In their evaluation of the forage module, they concluded that there was a need to improve the plant model's response to environmental stresses. The following 3 limitations to simulating plant responses to the environment were identified:

1. Initial biomass at emergence, storage:growth ratio, respiration rate, root mortality rate, and root:shoot ratio were considered site parameters and were not specific to each functional group. These limited the model's ability to simulate differences in seasonal growth patterns among the functional groups.

2. Emergence/green-up and start of senescence were the only phenological stages. These parameters were given as days of the year and not as heat units or photoperiod, which are more physiologically sound. The model was not appropriate for continuous multiyear simulations (i.e., required for strategic applications) because it could not simulate year-to-year variability in emergence/green-up and senescence as a function of climate.

3. The plant module did not simulate root growth and water uptake (transpiration) separately for each functional group. This made it impossible to simulate competition for soil water among functional groups.

The following improvements were made to the forage module to address the above limitations:

1. Initial biomass at emergence, storage: growth ratio, respiration rate, root mortality rate, and root:shoot ratio can now be specified separately for each functional group, resulting in better control of the simulated growth curves.

2. A simple phenology module based on heat units (growing degree days) was developed for rangeland plant functional groups. The critical growth stages considered are spring green-up/emergence (EmergGDD, $\left.{ }^{\circ} \mathrm{C} \cdot \mathrm{d}\right)$, end of vegetative growth, start of senescence, and maturity $\left(\right.$ Mature $\left.G D D,{ }^{\circ} \mathrm{C} \cdot \mathrm{d}\right)$. In addition, a simple algorithm was adapted from the SPUR plant component (Hanson et al. 1988) to estimate the amount of biomass translocated from live roots to the shoots at spring green-up.

3. The root growth, potential transpiration, and root water uptake algorithms were modified to simulate root growth and transpiration separately for each functional group. Leaf area index of each functional group is simulated to account for differences in light interception and subsequent transpiration.

In addition to the above improvements in the simulation of plant processes, the GPFARM forage module was reprogrammed in object-oriented Java for easier code improvement, maintenance, and debugging.

The improved forage module of GPFARM is a simplification of the SPUR plant model (Hanson et al. 1988). Live and dead 
Table 1. Critical forage parameters used in the forage growth simulations.

\begin{tabular}{|c|c|c|c|c|}
\hline \multirow[b]{2}{*}{ Parameter } & \multirow[b]{2}{*}{ Definition } & \multicolumn{3}{|c|}{ Functional group } \\
\hline & & Warm-season grasses & Cool-season grasses & Forbs \\
\hline GrRate $\left(\mathrm{kg} \cdot \mathrm{kg}^{-1} \cdot \mathrm{d}^{-1}\right)$ & Maximum relative growth rate of shoot & 0.22 & 0.18 & 0.17 \\
\hline $\operatorname{Tmax}\left({ }^{\circ} \mathrm{C}\right)$ & Maximum temperature for growth & 45 & 36 & 35 \\
\hline Topt $\left({ }^{\circ} \mathrm{C}\right)$ & Optimum temperature for growth & 30 & 20 & 20 \\
\hline $\operatorname{Tmin}\left({ }^{\circ} \mathrm{C}\right)$ & Minimum temperature for growth & 5 & 0 & 3 \\
\hline EmergGDD $\left({ }^{\circ} \mathrm{C} d\right)$ & Calendar year growing degree days to emergence or green-up & 70 & 200 & 105 \\
\hline MatureGDD ( $\left.{ }^{\circ} \mathrm{C} d\right)$ & Calendar year growing degree days to maturity & 1500 & 2200 & 1188 \\
\hline SenGDD $\left({ }^{\circ} \mathrm{C} d\right)$ & Calendar year growing degree days to start of senescence & 1400 & 1200 & 1685 \\
\hline SenRate $\left(\mathrm{kg} \cdot \mathrm{kg}^{-1} \cdot \mathrm{d}^{-1}\right)$ & Rate of tissue dying in the growing season & 0.001 & 0.001 & 0.002 \\
\hline FallRate $\left(\mathrm{kg} \cdot \mathrm{kg}^{-1} \cdot \mathrm{d}^{-1}\right)$ & Transfer of standing dead biomass to the ground & 0.008 & 0.008 & 0.010 \\
\hline
\end{tabular}

forage are simulated for 5 functional groups (warm-season grasses, cool-season grasses, forage legumes, shrubs, and unpalatable forbs) rather than for individual species. The model is deterministic and simulates average biomass production based on average plant, soil, and weather parameters that are assumed to represent a field or paddock. The proportion of the plant community in each functional group (PropPop, $0-1$ ) is specified by the user and should add up to 1.0. Biomass production for each functional group is calculated on the basis of a potential growth rate that is adjusted by nondimensional scalar multipliers for temperature and water stress factors:

$$
\Delta W=G r R a t e(\text { AboveBio })(E V P)
$$

where $\Delta W$ is daily change in biomass $\left(\mathrm{kg} \cdot \mathrm{ha}^{-1} \cdot \mathrm{d}^{-1}\right)$, GrRate is potential growth rate $\left(\mathrm{kg} \cdot \mathrm{kg}^{-1} \cdot \mathrm{d}^{-1}\right)$, AboveBio is aboveground live biomass $\left(\mathrm{kg} \cdot \mathrm{ha}^{-1}\right)$, and $E V P$ is the environmental fitness factor $(0-1)$ affecting forage production. Environmental fitness is quantified by

$$
E V P=E T P \cdot E W P
$$

where ETP is effect of temperature on production $(0-1)$ and EWP is effect of water availability on production $(0-1)$. Hanson et al. (1988) discuss the empirical basis for the functions, and the reader is referred to them for a detailed description. The ETP function is an empirical bell-shaped curve with minimum (Tmin), optimum (Topt), and maximum (Tmax) temperatures for growth determining its shape. The EWP is a threshold response curve that is a function of the ratio of actual evapotranspiration (ET) and potential ET. The current version of GPFARM does not explicitly consider nitrogen stress. This was not considered a major limitation in the current study because the simulated systems were natural rangelands with no commercial $\mathrm{N}$ fertilization and presumed to have stable, albeit low, plant-available $\mathrm{N}$ levels. Also, the effect of $\mathrm{N}$ stress is implicitly considered in the calibration of potential growth rate (GrRate) of each functional group. Plant respiration $\left(\mathrm{kg} \cdot \mathrm{ha}^{-1} \cdot \mathrm{d}^{-1}\right)$ is estimated by

$$
\text { Respiration }=\text { RespRate } \cdot W_{s}
$$

where RespRate is relative respiration rate $\left(0.04 \mathrm{~kg} \cdot \mathrm{kg}^{-1}\right.$ shoot biomass $\cdot \mathrm{d}^{-1}$ ) and $W_{s}$ is current biomass stored in the shoot $\left(\mathrm{kg} \cdot \mathrm{ha}^{-1}\right)$. Daily net assimilation by each functional group is the difference between $\Delta W$ and Respiration.
Senescence is also simulated by the use of a parameterized senescence rate $\left(\right.$ SenRate, $\left.\mathrm{kg} \cdot \mathrm{kg}^{-1} \cdot \mathrm{d}^{-1}\right)$ that takes effect after a specified number of growing degree days $\left(\operatorname{Sen} G D D,{ }^{\circ} \mathrm{C} \cdot \mathrm{d}\right)$. After senescence, aboveground biomass falls to the soil surface as litter at a parameterized rate (FallRate, $\left.\mathrm{kg} \cdot \mathrm{kg}^{-1} \cdot \mathrm{d}^{-1}\right)$. Root biomass is calculated by multiplying total aboveground biomass by the root:shoot ratio and assuming an exponential distribution in the soil profile (Weaver et al. 1935; Gill et al. 1999).

\section{Calibration of Forage Model}

The forage model was calibrated for conditions at the USDAARS High Plains Grasslands Research Station in Cheyenne, Wyoming (lat $41^{\circ} 11^{\prime} \mathrm{N}$, long $104^{\circ} 53^{\prime} \mathrm{W}$ ). The climate at the site is semiarid with an average annual precipitation of $384 \mathrm{~mm}$. Precipitation is lowest in December, increasing to a maximum in late May and early June, and remains moderate until fall, when it decreases again to a December minimum (Stevenson et al. 1984). Daily climate data were taken from the GPFARM historical climate database (extracted from National Climate Data Center databases) for Cheyenne, Wyoming. These included precipitation ( $\mathrm{mm})$, maximum and minimum air temperature $\left({ }^{\circ} \mathrm{C}\right)$, solar radiation (langleys $\left.\cdot \mathrm{d}^{-1}\right)$, mean wind speed $\left(\mathrm{m} \cdot \mathrm{s}^{-1}\right)$, and mean relative humidity $(\%)$. Daily precipitation is used in the model to calculate infiltration and soil water redistribution by the method described by Andales et al. (2003). Daily solar radiation, relative humidity, and wind speed are used to estimate potential ET by the extended ShuttleworthWallace method (Farahani and Ahuja 1996). Soil profile characteristics of Albinas loam, which is the dominant soil at the site, were obtained from the GPFARM soils database (derived from merged Natural Resource Conservation Service Soils-5 and Soils- 6 databases).

The forage model was calibrated against monthly total forage biomass collected in 1982 (Test 1984). Observed total biomass was an average from 4 temporary $1.9-\mathrm{m}^{2}$ exclosure cages with each cage having $20.18-\mathrm{m}^{2}$ clipped subplots. The exclosures were in season-long continuous grazed pastures with moderate stocking rates $\left(0.8 \mathrm{ha} \cdot \mathrm{AUM}^{-1}\right)$ and were moved a random distance and direction between each sampling date. The plant parameters in the GPFARM forage module were adjusted to get the best fit of the total biomass curve (Table 1). The magnitude and timing of peak growth were most sensitive to GrRate and Topt. Monson et al. (1983, 1986) provided ranges of Topt for warm-season and cool-season grasses that 
typically dominate the study site. The SenGDD and SenRate parameters had the greatest influence on biomass decline and were adjusted to obtain the best fit for the declining phase of the curves. The initial plant community composition in 1982 was estimated from onsite production data as follows: proportion of forage made up by warm-season grasses, PropPopWSG = 0.49; proportion of forage made up by coolseason grasses, PropPopCSG $=0.37$; proportion of forage made up by forbs, PropPopFb $=0.14$. Forage legumes and shrubs were rare.

\section{Strategic (Long-Term) Prediction of Forage Production}

After calibration with 1982 biomass data, the improved forage model was tested against 19 years (1983-2001) of observed annual peak standing crop (PSC) of herbage. Four $1.5-\mathrm{m}^{2}$ exclosures were randomly located on Albinas or similar soils in season-long continuous grazed pastures with moderate stocking rates and were moved prior to each grazing season in a random direction a random distance, conditional that the slope remained similar across years. In late July of each year, PSC was determined inside each exclosure by hand clipping a $0.18-\mathrm{m}^{2}$ quadrat to ground level or by capacitance meter reading, which was converted to a PSC value from a regression equation (Manley et al. 1997). Daily climate data (1983-2001) were taken from the GPFARM historical climate database (extracted from National Climate Data Center databases) for Cheyenne, Wyoming.

The model simulation covered the period of 1 January 1982 through 31 December 2001. The simulation of the rangeland dynamics in 1982 was done to allow the simulated soil water content and plant biomass to stabilize by the start of 1983, thus serving as the initial condition for the 1983-2001 simulated period. Soil water measurements that could be used to initialize the model for 1983 were not available. All the forage parameters were kept the same as the values from the calibration obtained using 1982 data (Table 1). The time series of observed PSC was compared to simulated PSC in each year. The performance of the model in simulating the trends in PSC as affected by climate over the 19-year period was assessed (see Model Evaluation) to determine the adequacy of the model for strategic (long-term) forage prediction. Empirical cumulative distribution functions (CDF) of both the observed and simulated time series of PSC were plotted using the ecdf and plot functions in R (R Development Core Team 2005). The 2-sample Kolmogorov-Smirnov (KS) test (Conover 1971) was performed to determine if the predicted and observed CDFs differed significantly. The ks.test function in $\mathrm{R}$ was used to perform the test.

\section{Tactical (Within-Season) Prediction of Forage Production}

The difficulty in predicting within-season forage production lies in forecasting the weather for the current growing season. We attempted to predict forage production in 1983 using a normal weather year identified from an analysis of historical weather. The year 1983 was chosen because monthly forage production data were available for comparison with model predictions (Test 1984). At the semiarid study site in Cheyenne, Wyoming, forage production is most sensitive to the amount of precipitation occurring in the growing season. We analyzed 67 years of precipitation record (1915-1981) from Cheyenne,
Wyoming, to determine the long-term mean of season precipitation (March-September of each year). The historical weather year with March to September precipitation closest to the long-term mean (herein referred to as the normal weather year) was used in the simulation to forecast forage production in 1983. In addition, the driest and wettest weather years from the 67-year record were used to predict the lower and upper bounds of probable forage production, respectively.

The initial forage forecast was made for 1 March 1983 onward using normal weather from 1 March onward. Subsequent forage forecasts were made for 1 April onward, 1 May onward, and 1 June onward, with actual weather until the start date of forecast being used in lieu of normal weather data. Onsite soil water content was not available for 1983 . Thus, the simulated period began on 1 January 1982 until each forecast start date (i.e., 1 March, 1 April, 1 May, and 1 June 1983) using actual weather data. The model-calculated soil water content at each forecast start date was used as the initial soil water content for the forecasted period. The accuracy of the forage forecast was expected to improve with each forecast update as actual weather data became available. For each simulation, the forecasted total forage biomass was compared with monthly observations taken in 1983.

\section{Model Evaluation}

Time-series plots of predicted $(p)$ and observed $(o)$ values as well as difference statistics were used in the evaluation of forage simulations. The mean and standard deviation of the modelpredicted $\left(\bar{p}, s_{p}\right)$ and the observed $\left(\bar{o}, s_{o}\right)$ forage production were calculated as well. The following difference statistics were calculated: mean bias error $(M B E)$, root mean square error (RMSE), and index of agreement $(d)$. Mean bias error shows the magnitude of the average over- or underprediction of the model and is expressed as

$$
M B E=\frac{\sum_{i=1}^{n}\left(p_{i}-o_{i}\right)}{n}
$$

where $p_{i}$ is the $i$ th predicted value, $o_{i}$ is the $i$ th observed value, and $n$ is the number of data pairs. The RMSE, which shows the average deviation between predicted and observed values regardless of sign, was calculated by

$$
R M S E=\sqrt{\frac{\sum_{i=1}^{n}\left(p_{i}-o_{i}\right)^{2}}{n} .}
$$

The index of agreement, $d$, which gives the proportion of the observed variance that is explained by the model, was calculated as proposed by Willmott (1981) and Willmott and Wicks (1980):

$$
d=1-\left[\frac{\sum_{i=1}^{n}\left(p_{i}-o_{i}\right)^{2}}{\sum_{i=1}^{n}\left(\left|p^{\prime}{ }^{\prime}\right|+\left|o^{\prime} i\right|\right)^{2}}\right], \quad 0 \leq d \leq 1
$$

where $p_{i}, o_{i}$, and $n$ are as previously defined, $p_{i}{ }^{\prime}=p_{i}-\bar{o}$, and $o_{i}{ }^{\prime}=o_{i}-\bar{o}$, where $\bar{o}$ is the observed mean and the enclosing 


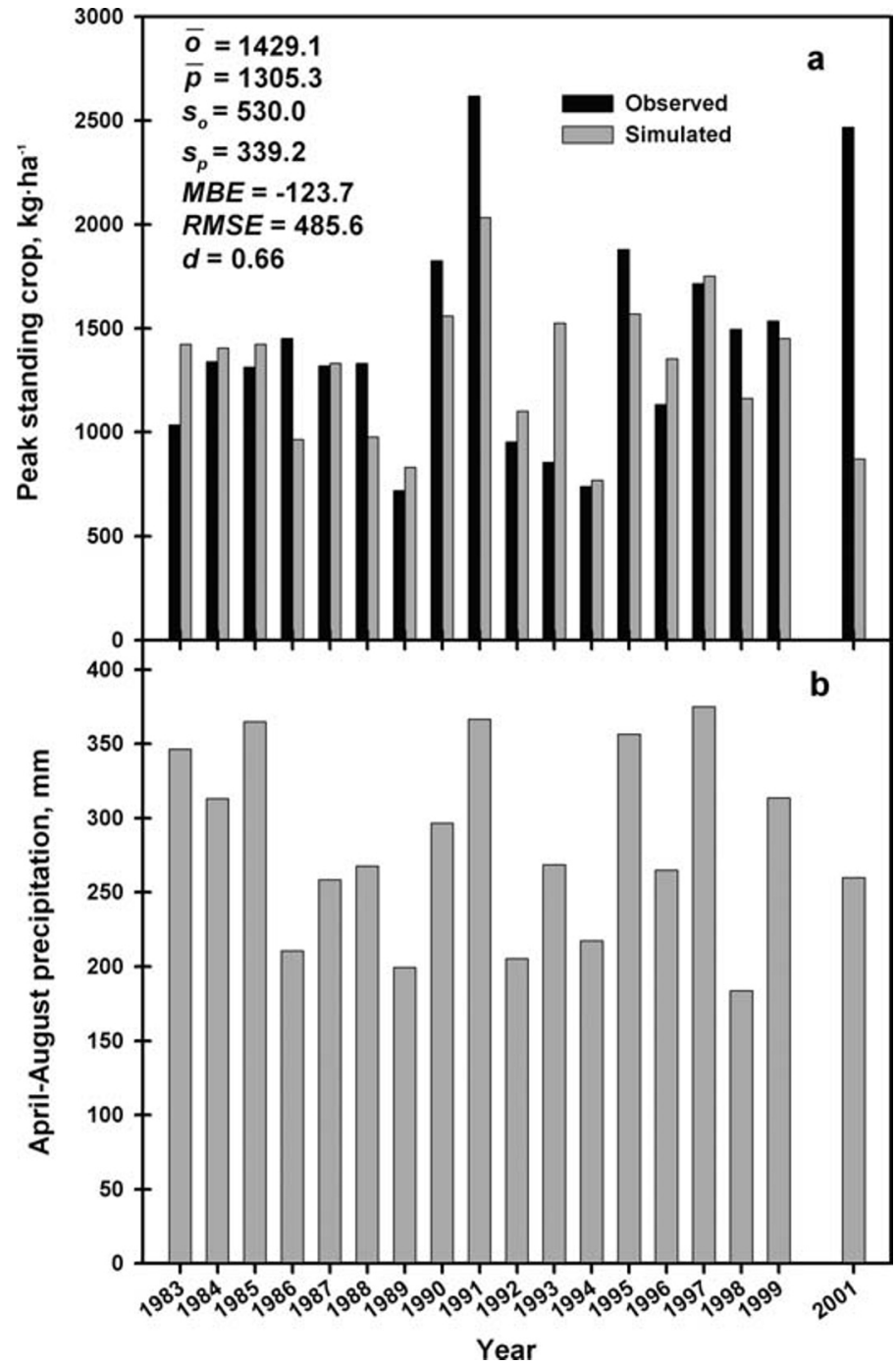

Figure 1. Results of continuous long-term simulation of forage production using the improved GPFARM forage model. Observed and simulated values of peak standing crop (PSC) (a) are shown from 1983 to 2001 for a northern mixed-grass prairie site in Cheyenne, Wyoming. Corresponding April-August precipitation totals (critical period of growing season) are also shown (b). The PSC was not measured in 2000 because of a severe drought. The year 2000 was excluded from the statistics. Statistics shown are observed and predicted mean $(\bar{o}$ and $\bar{p}$, respectively), observed and predicted standard deviation ( $s_{o}$ and $s_{p}$, respectively), mean bias error $(M B E)$, root mean square error (RMSE), and index of agreement $(d)$.

bars $(||)$ indicate absolute values. Zero (0) and one (1) bound the $d$ statistic, where 1 indicates complete agreement between $p$ and $o$. In the evaluation of model accuracy, the 1:1 line corresponds to perfect agreement between $o$ and $p$ when $p$ is plotted against $o$. While the coefficient of determination $\left(r^{2}\right)$, which is commonly used to report model accuracy, is a measure of the tightness of the linear relationship between $o$ and $p$ relative to the regression line, $d$ is a measure of the tightness of the linear relationship relative to the $1: 1$ line. The $r^{2}$ can be a misleading measure of accuracy (Willmott 1982), as the regression line can deviate considerably from the 1:1 line; therefore, $d$ was used in lieu of $r^{2}$ in this study.

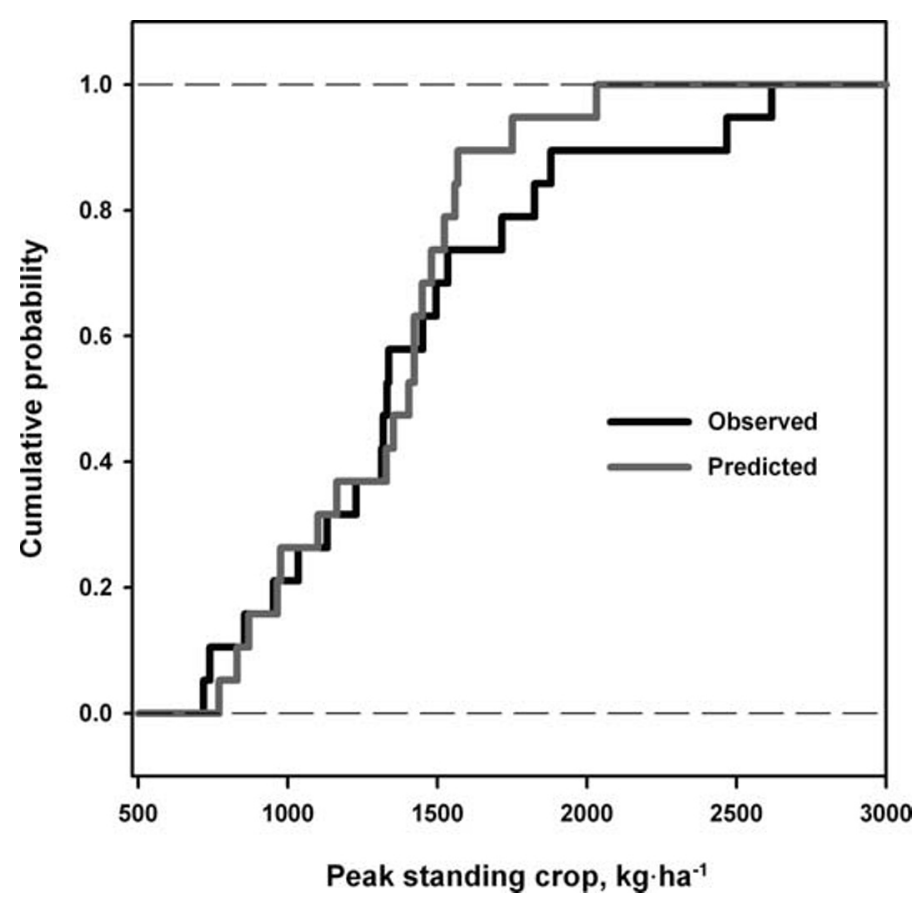

Figure 2. Empirical cumulative distribution functions of observed and simulated peak standing crop (1982-2001) at the northern mixed-grass prairie site in Cheyenne, Wyoming.

\section{RESULTS AND DISCUSSION}

\section{Strategic Prediction of Forage Production}

The simulation model explained $66 \%$ (i.e., $d=0.66$ ) of the variability in PSC from 1983 to 2001 (Fig. 1). The predicted mean PSC for the period was $8.7 \%$ lower than the observed mean. Over the period of simulation, the model had a bias to underpredict PSC (negative $M B E=-123.7$ ). Overall, the model tracked the observed year-to-year variability in PSC. However, the time series of predicted PSC did not show the same degree of variability as observed $\left(s_{p}<s_{o}\right)$. The largest error in simulated PSC occurred in 2001, which was a year immediately following a severe drought. In fact, no observations of PSC were taken in 2000 because of very low forage production. The model could not simulate the apparently quick recovery of the vegetation from the severe drought. Andales et al. (2005) observed a similar model deficiency in shortgrass prairie, where the model could not simulate late-season recovery of vegetation. With the exception of 2001, the model did explain $83 \%$ of the variability in PSC (1983-1999).

One strategic application of the forage simulation model is the estimation of a time series of PSC at a location. The CDF of the time series can then be used to estimate probabilities of forage production. The CDF of PSC provides an estimate of the probability of PSC being less than or equal to certain amounts (i.e., cumulative probability). The converse of cumulative probability (i.e., 1.0 - cumulative probability) may be more useful in deciding on a stocking rate because it is an estimate of the probability of PSC being equal to or greater than a certain amount.

The empirical CDFs for the observed and predicted values of PSC (1982-2001) are both shown in Figure 2. The predicted 


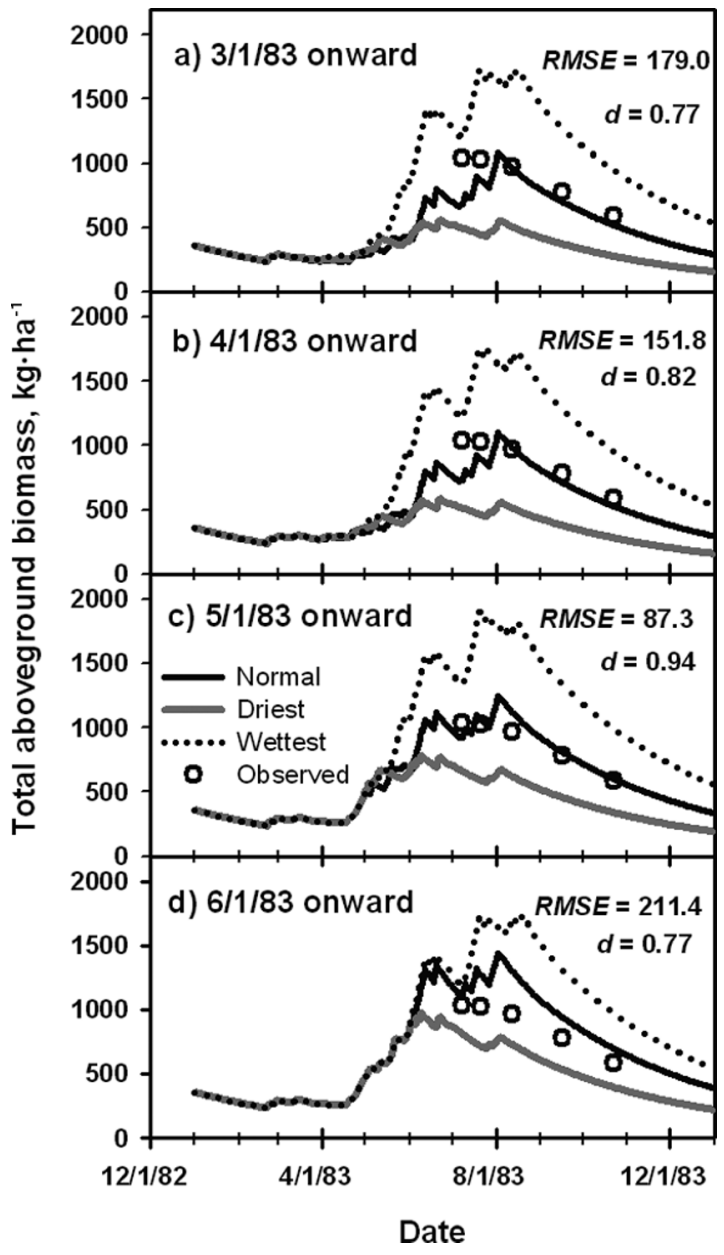

Figure 3. Forecasts of total aboveground biomass (dry matter) for 4 forecasted periods in 1983 at the northern mixed-grass prairie site in Cheyenne, Wyoming.

CDF has a steeper slope and smaller range than the observed CDF. These indicate that predicted PSC has less variability than observed PSC. The predicted CDF gives higher cumulative probabilities for PSCs greater than $1500 \mathrm{~kg} \cdot \mathrm{ha}^{-1}$. This is another way of saying that the model tends to underpredict PSC values greater than $1500 \mathrm{~kg} \mathrm{ha}^{-1}$. Thus, if the predicted CDF were to be used in deciding stocking rates, it would err on the conservative side for PSCs greater than $1500 \mathrm{~kg} \cdot \mathrm{ha}^{-1}$. For example, it estimates that $80 \%$ of the time, PSC will be less than or equal to $1600 \mathrm{~kg} \cdot \mathrm{ha}^{-1}$. The observed CDF estimates that $80 \%$ of the time, PSC will be less than or equal to $\sim 1800$ $\mathrm{kg} \cdot \mathrm{ha}^{-1}$. Therefore, the predicted CDF is potentially useful within the 500-1 $500 \mathrm{~kg} \cdot \mathrm{ha}^{-1}$ PSC range. Better agreement between simulated and observed CDFs is expected with further model improvements.

The KS test failed to reject the null hypothesis that the observed and predicted empirical CDFs come from the same distribution. The maximum separation (error) in the cumulative distributions (D parameter) was 0.1579 , while the $P$ value was 0.978 . This provided some evidence that the forage model can potentially be used to generate a long-term time series of PSC values having a realistic distribution that is characteristic of the prairie site at Cheyenne, Wyoming.
A cursory comparison of trends in observed PSC and season precipitation (Figs. 1a and 1b) reveals that PSC is not always directly related to the amount of precipitation. For example, April-August precipitation in 1985, 1991, and 1997 were all relatively high but did not result in similar levels of PSC. Indeed, the timing of precipitation, initial soil water, growing degree-days, and other environmental factors have to be considered in making strategic predictions of forage production. While most of these factors have been incorporated in the forage model, the simulated interactions and effects on forage production will need closer examination. Other factors still need to be incorporated in the model. For example, the direct effect of solar radiation on forage growth is not explicitly modeled, and simulated plant growth is driven by air temperature. Data collection for these model improvements will require intensive field observations involving frequent aboveand belowground biomass observations, phenological observations, and continuous monitoring of weather and soil water.

\section{Tactical Prediction of Forage Production}

The analysis of long-term precipitation records at Cheyenne, Wyoming, indicated that 1953 had seasonal precipitation closest to normal. The year 1923 was the wettest year, while 1964 was the driest. The March-September precipitation totals were 302, 456, and $136 \mathrm{~mm}$ in 1953, 1923, and 1964, respectively. Weather data from these years were used in the model to give the normal, wettest, and driest forecasts in 1983. Actual March-September precipitation in 1983 was $441 \mathrm{~mm}$, which was above normal. It was shown in the previous section that the model simulated less variability in PSC than observed, especially underestimating high values. Therefore, the probable range of biomass production may be greater than that indicated by the wettest and driest forecasts given here.

The progression of updated forecasts, initially for 1 March 1983 onward, is shown in Figure 3. For each forecasted period, the normal forecast was taken as the best estimate of total biomass, while the driest and wettest forecasts gave the lower and upper bounds of probable forage production. The accuracy of the normal forecast improved as the forecast was updated for 1 April 1983 onward and 1 May 1983 onward. Index of agreement $(d)$ increased and RMSE decreased from the 1 March 1983 forecast start date to the 1 May 1983 forecast start date (Fig. 3a-3c). The model underpredicted forage biomass in July for the forecasts made for 1 March 1983 onward and 1 April 1983 onward. The most accurate forecast was obtained for 1 May 1983 onward, with the normal forecast explaining 94\% $(d=0.94)$ of within-season biomass variability. The normal forecast for 1 June 1983 onward was not the most accurate, and it overestimated biomass production (Fig. 3d).

This discrepancy may be explained by realizing that accuracy of the forecasted biomass curves was related to how close the forecasted precipitation tracked actual patterns. Actual weather data were used until the start date of forecast, after which normal weather (i.e., from 1953) was used. The forecasted cumulative precipitation was closest to the actual values in the forecast with a 1 May 1983 start date (Fig. 4). Therefore, this forecast was the most accurate. Cumulative precipitation amounts were underestimated in the forecasts with 1 March 1983 and 1 April 1983 start dates compared to actual 1983 


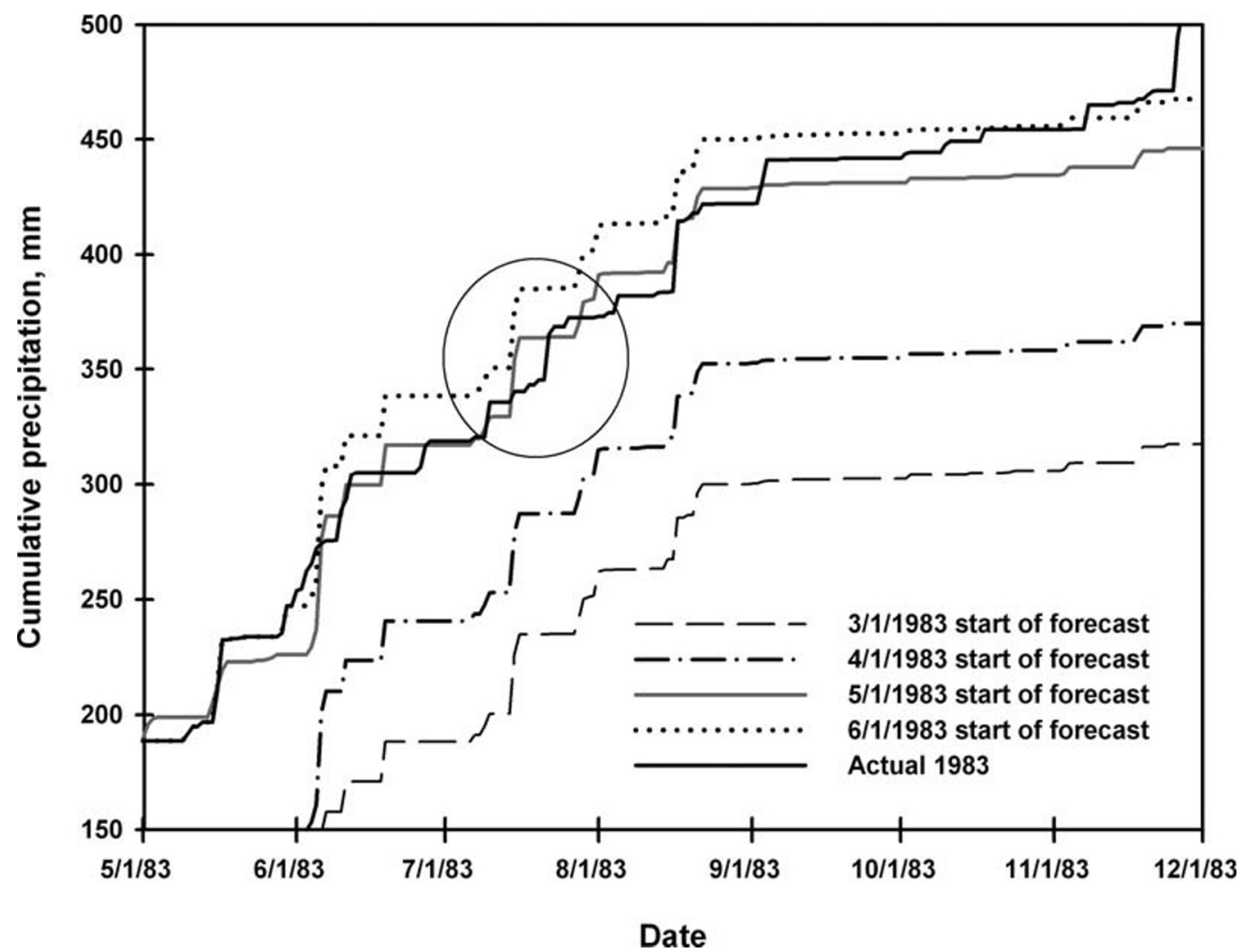

Figure 4. Cumulative precipitation for different forecast start dates in 1983. The region encircled highlights how much cumulative precipitation for the case of 1 June 1983 start of forecast has deviated from the actual values by July, when peak biomass usually occurs.

precipitation. This resulted in underpredictions of total biomass in July. Cumulative precipitation was overestimated in the forecast with 1 June 1983 start date and resulted in overpredictions of biomass. Total aboveground biomass peaked in July. The region encircled in Figure 4 highlights how much cumulative precipitation for the case of 1 June 1983 start of forecast has deviated from the actual values by July, when peak biomass usually occurs. Thus, the accuracy of the normal forecast depends on the similarity between normal and actual weather.

Because of the uncertainty in using normal weather to forecast forage production, the driest and wettest weather are used to derive lower and upper bounds of probable forage production. The decision maker can then speculate whether forage biomass will be above or below the normal forecast while staying within the lower and upper bounds. These "adjustments" to the normal forecast can be made if seasonal precipitation is forecasted to be above or below normal and the forecasts are reliable. The Climate Prediction Center (CPC) of the National Weather Service provides short-term and longterm outlooks for both temperature and precipitation for the continental United States that can help guide adjustments in the forage forecast (http:/www.cpc.ncep.noaa.gov/products/ OUTLOOKS_index.shtml). Although previous CPC seasonal precipitation forecasts were shown to have limited agricultural utility in the northern Great Plains (Schneider and Garbrecht 2003), improvements in climate forecasting skill should increase the utility of these forecasts in the future. For the northern mixed-grass prairie site considered in this study, we found that simulations of PSC were directly related to total precipitation from April to May (Fig. 5). This was found to be true at different levels of initial soil water content (SWCi) on 1 May 1983. Each SWCi value was input into the model as the

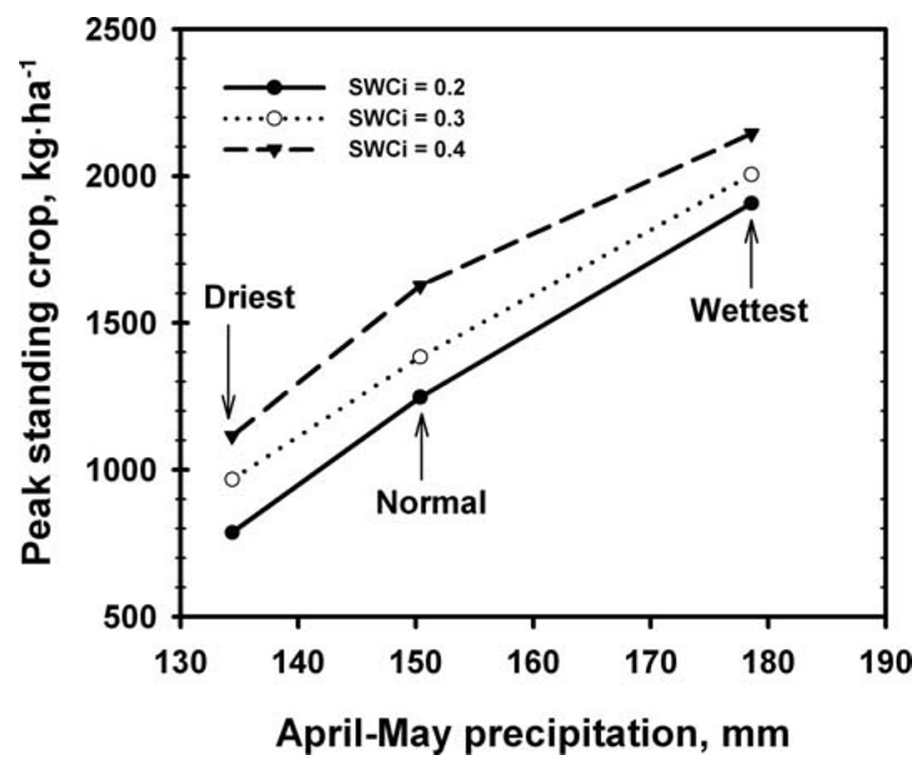

Figure 5. Peak standing crop forecasted for the period 1 May 1983 onward, related to April-May precipitation and initial volumetric soil water content (SWCi) on 1 May 1983 in the top 2 soil horizons (0-81 $\mathrm{cm}$ ) at the northern mixed-grass prairie site in Cheyenne, Wyoming. 
initial condition for the driest, normal, and wettest forecasts for 1 May 1983 onward. Thus, a family of simulated curves may be used to forecast PSC based on knowledge of initial soil water content and anticipated level of April-May precipitation at the site (e.g., Fig. 5).

\section{MANAGEMENT IMPLICATIONS}

We illustrate the use of the above simulation results through 2 examples, 1 each for strategic and tactical planning. For strategic planning, Rancher $\mathrm{A}$ at the northern mixed-grass prairie site in Cheyenne, Wyoming, would like to determine the PSC that is equaled or exceeded $80 \%$ of the time. The rancher would like to base the long-term stocking rate on this level of forage production. Assume that a long-term record of PSC is not available. Rancher A uses the CDF of predicted PSC (Fig. 2) to estimate the PSC that has a 0.8 probability of being equaled or exceeded (i.e., cumulative probability $=1.0-0.8=0.2$ ). From the predicted CDF in Figure 2, Rancher A determines that $\mathrm{PSC}=975 \mathrm{~kg} \cdot \mathrm{ha}^{-1}$ has a cumulative probability of 0.2 . The rancher then estimates the number of livestock that can be supported by $975 \mathrm{~kg} \cdot \mathrm{ha}^{-1}$ of forage production.

For tactical planning, Rancher A wanted to adjust the stocking rate on 1 May 1983 based on forecasted forage production. At this date, the rancher knew that the average volumetric soil water content was 0.2 . A nearby airport had a weather station with long-term records of daily weather. Rancher A had a consultant who previously calibrated the forage simulation model for the ranch. The consultant ran the model using the normal, driest, and wettest weather years on record to generate Figure 5. Rancher A knew that the ranch received 113 $\mathrm{mm}$ of precipitation in April 1983. The National Weather Service projected that precipitation in May $1983 \mathrm{had}$ an equal chance of being above or below normal. Rancher A then speculated that the ranch would receive the normal amount of precipitation in the April-May period. Therefore, Rancher A looked at the line for SWCi $=0.2$ in Figure 5, took the point at normal April-May precipitation $(150 \mathrm{~mm})$; and determined that a peak standing crop of $1240 \mathrm{~kg} \cdot \mathrm{ha}^{-1}$ could be expected. Rancher A then adjusted the stocking rate to a level that could be supported by $1240 \mathrm{~kg} \cdot \mathrm{ha}^{-1}$ of forage production.

The 2 examples assumed that adequate information was available to calibrate the forage simulation model and that the forecasts were reliable. Similar applications of the model at other locations will require at least 1 season in which biomass growth, preferably by functional group, has been observed or sampled. Soil layer textures (\% sand, silt, clay) and bulk densities of a representative soil profile must also be available for input to the model. Daily weather records may be from an on-site or nearby weather station. Also, long-term weather records are needed to generate a simulated cumulative distribution function of PSC. These are also needed to identify the normal, wettest, and driest weather years.

This study demonstrated that the improved GPFARM forage model could be used to generate a CDF of simulated PSC, with tolerable errors (66\% explained variance). The generated CDF could be used strategically to estimate long-term forage production at various levels of probability. The use of the model for tactical forage prediction was also demonstrated. The model forecasts explained $77 \%-94 \%$ of within-season biomass variability in 1983. It was shown that monthly updating of the early-spring forecast, with input of actual weather to date, improves accuracy. Further development and testing of the forage simulation model will focus on the interactions between forage growth, environmental perturbations (especially drought), and grazing. The simulation of recovery of vegetation after a drought period must be improved. Other aspects of the model, such as root dynamics and the soil water balance, will be studied as appropriate field data become available.

\section{ACKNOWLEDGMENTS}

Stanley Clapp, Pam Freeman, and numerous student workers collected peak standing crop values during this study at the High Plains Grasslands Research Station. We appreciate Dr Mark West's guidance in the choice of statistical functions in R. We thank Dr John Hendrickson, Dr Jeanne Schneider, and 3 anonymous persons for reviewing the manuscript.

\section{LITERATURE CITED}

Andales, A. A., L. R. Ahuja, and G. A. Peterson. 2003. Evaluation of GPFarm for dryland cropping systems in eastern Colorado. Agronomy Journal 95: 1510-1524.

Andales, A. A., J. D. Derner, P. N. S. Bartling, L. R. Ahuja, G. H. Dunn, R. H. Hart, and J. D. HANSON. 2005. Evaluation of GPFARM for simulation of forage production and cow-calf weights. Rangeland Ecology \& Management 58:247-255.

BIondinI, M. E., AND L. Manske. 1996. Grazing frequency and ecosystem processes in a northern mixed prairie. Ecological Applications 6:239-256.

Biondini, M. E., B. D. Patton, and P. E. Nyren. 1998. Grazing intensity and ecosystem processes in a northern mixed-grass prairie. Ecological Applications 8:469-479.

CONOVER, W. J. 1971. Practical nonparametric statistics. New York, NY: John Wiley and Sons. p 309-314.

Farahani, H. J., AND L. R. AhuJA. 1996. Evapotranspiration modeling of partial canopy/residue-covered fields. Transactions of the American Society of Agricultural Engineers 39:2051-2064.

Gill, R. A., I. C. Burke, D. G. Milchunas, and W. K. Lauenroth. 1999. Relationship between root biomass and soil organic matter pools in the shortgrass steppe of eastern Colorado: implications for decomposition through a soil profile. Ecosystems 2:226-236.

Hanson, J. D., J. W. Skiles, and W. J. Parton. 1988. A multispecies model for rangeland plant communities. Ecological Modelling 44:89-123.

Hart, R. H., M. J. Samuel, P. S. Test, And M. A. Smith. 1988. Cattle, vegetation, and economic responses to grazing systems and grazing pressure. Journal of Range Management 41:282-286.

Heitschmidt, R. K., M. R. Haferkamp, M. G. Karl, and A. L. Hild. 1999. Drought and grazing: I. Effects on quantity of forage produced. Journal of Range Management 52:440-446.

Khumalo, G., AND J. HoleCHeK. 2005. Relationships between Chihuahuan Desert perennial grass production and precipitation. Rangeland Ecology \& Management 58:239-246.

Knapp, A. K., AND M. D. Smith. 2001. Variation among biomes in temporal dynamics of aboveground primary production. Science 291:481-484.

Launchbaugh, J. L. 1967. Vegetation relationships associated with intensity of summer grazing on a clay site in the Kansas 20-24 precipitation zone. Kansas Agricultural Experiment Station Technical Bulletin 154. 24 p.

Manley, W. A., R. H. Hart, M. J. Samuel, M. A. Smith, J. W. Waggoner, JR., and J. T. Manley. 1997. Vegetation, cattle, and economic responses to grazing strategies and pressures. Journal of Range Management 50:638-646.

Monson, R. K., R. O. LitTlejohn, JR., and G. J. Williams III. 1983. Photosynthetic adaptation to temperature in four species from the Colorado shortgrass steppe: a physiological model for coexistence. Oecologia 58:43-51. 
Monson, R. K., M. R. Sackschewsky, and G. J. Williams III. 1986. Field measurements of photosynthesis, water-use efficiency, and growth in Agropyron smithii $\left(\mathrm{C}_{3}\right)$ and Bouteloua gracilis $\left(\mathrm{C}_{4}\right)$ in the Colorado shortgrass steppe. Oecologia 68:400-409.

PARSCH, L. D., M. P. PoPP, AND O. J. LoEWER. 1997. Stocking rate risk for pasture-fed steers under weather uncertainty. Journal of Range Management 50:541-549.

R Development Core Team. 2005. R: A language and environment for statistical computing. R Foundation for Statistical Computing, Vienna, Austria. Available at: http://www.R-project.org. Accessed 13 June 2006.

Schneider, J. M., and J. D. Garbrecht. 2003. A measure of the usefulness of seasonal precipitation forecasts for agricultural applications. Transactions of the American Society of Agricultural Engineers 46(2):257-267.

Stevenson, A., R. E. Baumgartner, and G. E. Schuman. 1984. High Plains Grasslands Research Station detailed soil survey. USDA-ARS, Wyoming Agricultura Experiment Station, USDA-SCS. $100 \mathrm{p}$.
TEST, P. S. 1984. Vegetation and livestock response to three grazing systemsContinuous, rotationally deferred and short-duration rotation [dissertation]. Laramie, WY: University of Wyoming. $91 \mathrm{p}$.

Weaver, J. E., V. H. Houghen, and M. D. Weldon. 1935. Relation of root distribution to organic matter in prairie soil. Botanical Gazette 96:389-420.

Wight, J. R., C. L. Hanson, and D. Whitmer. 1984. Using weather records with a forage production model to forecast range forage production. Journal of Range Management 37:3-6.

WilımotT, C. J. 1981. On the validation of models. Physical Geography 2:184194.

WiLlmotT, C. J. 1982. Some comments on the evaluation of model performance. Bulletin of the American Meteorological Society 63:1309-1313.

Willmott, C. J., AND D. E. Wicks. 1980. An empirical method for the spatial interpolation of monthly precipitation within California. Physical Geography 1:59-73. 